\title{
THE EXPERIENCE OF “CONSOLATION” IN THE LITTERAE INDIPETAE
}

\author{
Paulo Roberto de Andrada Pacheco \\ Marina Massimi
}

\begin{abstract}
The analysis of a particular type of Jesuit correspondence - the Litterae Indipetae - reveals the dynamism of the elaboration of experience which helps in the understanding of the modus vivendi that is based on what is commonly known as "Aristotelic-Thomist philosophical psychology". This article aims at showing the lived experience described in the letters and this specific modus vivendi (with its particular implications) as an attempt to answer the question: to what extent "consolation" - expressed through its own topoi of the genre of writing they are and the Jesuit's forma mentis (in a peculiar historical-cultural-institutional scope) - can interest modern psychology? As a result of this inquiry, it was found that the elaboration of "consolation", in the precise scope just described, considers that man is a unity (body and soul, reason and faith, sensation and intellect) and that, by living in order (with his own self and the world that surrounds him), it is possible for man to experience full joy and delight in analogy with the Divine Being.
\end{abstract}

Key words: Experience; Society of Jesus; Litterae Indipetae - jesuit correspondence.

\section{A EXPERIÊNCIA DE “CONSOLAÇÃO” NAS LITTERAE INDIPETAE}

RESUMO. Partindo da análise de um tipo de correspondência epistolar jesuítica - as Litterae Indipetae -, revelou-se um dinamismo de elaboração de experiência típico de um modus vivendi baseado no que comumente se vem designando sob o nome de "psicologia filosófica aristotélico-tomista". O presente artigo dedica-se justamente a este vivido particular descrito nessas cartas (com suas devidas implicações particulares). Além de dar voz aos indipetentes, buscou-se responder a uma pergunta: em que medida o topos "consolação" tal como é utilizado no ambiente histórico-cultural-institucional da Companhia de Jesus, nos séculos XVI e XVII - pode interessar à psicologia moderna? Como resultado, percebeu-se que a elaboração da experiência de consolação, precisamente no espaço conceitualgramatical acima descrito, parte da consideração de que o homem é uma unidade (corpo/alma, razão/fé, sensação/intelecto) e, vivendo ordenado (em si mesmo e no mundo que o cerca), pode experimentar a alegria e o prazer da realização, analogia do Ser Divino.

Palavras-chave: Experiência; Companhia de Jesus; Litterae Indipetae - correspondência epistolar jesuítica.

\section{LA EXPERIENCIA DE “CONSOLACIÓN” EN LAS LITTERAE INDIPETAE}

RESUMEN. El análisis de un tipo particular de correspondencia jesuítica - las Litterae Indipetae - ha revelado el dinamismo de la elaboración de la experiencia típica del modus vivendi que se basa en lo que se conoce comúnmente como "psicología filosofica aristotélico-tomista". Este artículo se dedica exactamente a este vivido particular descrito en estas correspondencias (con suas devidas implicaciones). Además de dar voz a los indipetentes, buscose contestar a una pregunta: ¿en qué medida el topos "consolación" - así como es utilizado en el ambiente historico-cultural-institucional de la Compañía de Jesús, en siglos XVI y XVII - puede ser de interés a la psicología moderna? Como resultado, percibióse que la elaboración de la experiencia de consolación, en el espacio conceptual-gramatical descripto, parte de la consideración de que el hombre es una unidad (cuerpo/alma, razón/fe sensación/intelecto) y que el vivir ordenado (en sí mismo y en el mundo que le rodea), puede experimentar la alegría y el placer de la realización, analogía del Ser Divino.

Palabras-clave: Experiencia; Compañía de Jesús; Litterae Indipetae - correspondencia jesuítica.

It is very usual to take for granted the meaning of some words. This attitude, depending on the worth of such word to the person's understanding, may determine the slavery to the average mentality and, consequently, define this person's complete alienation (see Giussani, 2000). To flee from this alienation is the task of the "intellectus cogitabundus", the living intelligence, which only moves towards what it

\footnotetext{
Psicológo. Doutor em Psicologia e pós-doutorando no IEL/UNICAMP. Professor da Universidade de São Paulo, Brasil.

\# Psicóloga. Doutora em Psicologia Experimental. Professora Títular da Universidade de São Paulo, Ribeirão Preto/SP, Brasil.
} 
considers as relevant. Indeed, "the operating intelligence infers a method" (Giussani, 2000, pp. 126, our translation) when it strives to get to know the object and makes the subject pay attention to his or her own existence.

In the present article we analyze the experience of the Jesuits from the XVI and XVII centuries. Our purpose here is to identify the concepts of the "gestational phase" ("pre-history") of Psychology that came to be, afterwards, subject matter of the Scientific Psychology. We chose the Society of Jesus because it is recognized as an important "cultural actor" (see Fabre \& Romano, 1999; Massimi, 2001; Massimi \& Prudente, 2002), responsible for the building, transmission and preservation of the PortugueseBrazilian culture in anthropological-philosophical and theological levels. Our concern here is to focus on the Jesuits' experience of consolation, understood as part of a broader psychological dynamism named here as "experience of freedom".

The primary sources used in this work were the Litterae Indipetae: letters through which young Jesuits of the XVI and XVII centuries requested the Superior General of the Society of Jesus to be sent in mission to the "Indies" (a general term for the territories of mission in the cultural and institutional scope studied). Nowadays, these letters are kept in the Archivum Romanum Societatis Iesu (ARSI) in Rome. It can be said that they are interesting sources for studies because these letters contain examples of the modalities of personal elaboration of experience concerning the process of election to which the Jesuits were educated. They also contain pertinent information about the indipetente (or "petitioner") such as age, school education, activity developed in the Order, among others. Moreover, the Litterae Indipetae analysed here contain edifying content and represent a specific genre of rhetoric - writing of letters - which follows the rules of the ars dictaminis. For that reason, these letters are better understood if they are read as icons of their particular sociocultural context, with its clear distinctions from others.

It is known that, in ARSI, there are 14.067 Indipetae letters written by 5.167 European Jesuits of several nationalities between 1583 and 1770 (see Lamalle, 1981-1982). However, we had to fix limits in this large corpus for the present research. The object of study was therefore determined by the restricted access we had to only part of the documents in ARSI and also by the own restrictions of the method used in the research. Thus, we have opted to work with a small number of Spanish letters, written during the period that Father Cláudio Aquaviva was Superior
General (between 1581 and 1615): the corpus is constituted by an amount of 26 letters, being 23 sent to Spain by 23 different Jesuits and 3 by the same Spanish Jesuit.

We also consulted some founding documents of the Society of Jesus in this research: texts about the peculiar modus cogitandis of this religious Order (their philosophical-rhetorical basis) - one of the guides to the Conimbricense Course (comments on Nicomachean Ethics) -, and other texts that represent the modus operandi specific to the Jesuits, as they contain the rules to be followed, being them the rules of spirituality: The Spiritual Exercises, A Pilgrims's Journey - The Autobiography of St. Ignatius of Loyola and Spiritual Diary, and the ones related to law: Constitutions, some Letters and Founding Texts.

Our general purpose here is to show how the philosophical, theological and psychological categories that give support to this particular way of living, the incarnation of some norms and theories appear in the Indipetae letters. These categories emerge from the analysis of the cultural topoi and they are institutionally determiners of a formal protocol of writing. This article is based exactly on the scope of systematized knowledge commonly referred to as Aristotelic-Thomist philosophical psychology, as well as on the studies of different genres of documents derived from it (guides about philosophy, treats of spirituality, letters, etc) and researches about it (see Longo, 1981; Massimi \& Prudente, 2002; Pécora, 1999 \& 2001; Tin, 2003).

Bearing in mind that man's education, according to the Ignatian perspective, is considered the guide that conducts the Jesuit through reality (See FernándezMartos, 1991), it can be affirmed that this pedagogy aims at leading the Jesuit to the final consolation, something that moves every man. It might be argued that this final consolation, the most perfect one, achieved only when seeing "face to face", could withstand the possibility of having the true experience of freedom, pushing it to a distant future, which is so distant as the end of someone's life or as the Indies overseas. Nevertheless - and it is a point defended by the Jesuits themselves - this is a hic et nunc experience, or "already and not yet": it is a fraction, here and now, of what it is the future eternity, or in Pedro Ruiz's (ARSI, Indipetae Hispanae, FG 758, Letter no. 188) and Diego de Salcedo's (ARSI, Indipetae Hispanae, FG 758, Letter no. 191) words in their Indipetae:

And, to restate my truest intentions, it is convenient to describe how I have persisted for such a long time in cultivating them, and how Our Lord has provided me with comfort when my intentions are often renewed; hence, each time I hear about the 
persecutions of those away and the work developed by our brothers overseas, I feel a new flame inside, and joy, and I confirm my inner intentions ${ }^{1}$ (ARSI, Indipetae Hispanae, FG 758, Letter no. 188, our translation) written by Ruiz, on July 29, 1593.

Since I was admitted to the Society, God has filled me with the desire to work in the Indies. When I was in the novitiate, they used to read aloud some letters written by Priests who were in Japan and other places and I appreciated listening to them. I felt as if it happened to me, as if I was there, living with them, and my desires increased and now as time has passed, they are really strong ${ }^{2}$ (ARSI, Indipetae Hispanae, FG 758, Letter no. 191, our translation) - reports Salcedo, on May 31, 1594.

The text now turns to the way the topos of consolation appears in the founding documents of the Society of Jesus. After this illustration, we will verify the dynamics of the experience described in the other Indipetae analyzed.

If we revisit Moral Philosophy - the science that deals with "the man while acts freely and can be improved with good habits and reach human happiness"3 (Góis, 1593/1957, pp. 61, our translation) according to the Aristotelic-Thomist perspective -, we find relevant distinctions in the "Third Dispute" of Conimbricense Course ("Of Happiness"). For example, in the first discussion, Góis (1593/1957) declares beatitudinem nihil aliud esse, quam summum hominis bonum ${ }^{4}$ (pp. 105). And he asks, what it is the Highest Good: external goods? goods of body? goods

1 "Y para que mas clara noticia tenga Vuestra Paternidad de mis deseos me parecio convenir dar quenta asi de la perseverancia en ellos tanto tiempo a como del consuelo que Nuestro Señor me comunica en renovarlos a menudo que cierto es grande y asi todas las veces que oygo tratar destas cosas y especialmente de persecuciones y trabajos que padecen los nuestros en aquellas partes siento en mi un nuevo fervor y una nueba alegria y me confirmo mucho mas en mis deseos".

2 "Desde el principio, que entre en la Compañia me dio Nuestro Señor siempre deseos de ir alas Indias, tanto que quando estava enel noviciado y se leian las cartas de Japon y otras partes de los Padres, me consolava mucho de oyelas, y me regozijava interiormente pareciendome que yo me hallaria alla con ellos conviviendo, y me crecian los deseos, y aora que esta movida el agua son muy grandes".

3 "o homem enquanto atua livremente e se pode aperfeiçoar com os bons costumes e alcançar a felicidade humana".

4 Beatitude is nothing more than man's Highest Good (our translation). of soul? After considering each inquiry, the author concludes:

As it is convenient to consider happiness the state of being happy, and as it was shown in the previous Dispute, happiness does not reside in the goods of body. Thus, it can be concluded that it resides in the goods of soul. Besides, as the goods of soul, generally speaking, are the powers, faculties and operations, and the two first mentioned are ordered to operation, and happiness is desired for its own nature - it can be stated, therefore, that happiness consists of the operation of $\operatorname{soul}^{5}$ (pp. 119, our translation).

The commentary to Aristotle's work goes on analyzing the differences between "supernatural happiness" (in this or in the future life) and "natural happiness" (practical or contemplative), and, at the end of the disputatio, Góis (1593/1957), based on Aristotle's definition - "felicitas est operatio animae per rationem, aut non sine ratione, secundum virtutem in vita perfecta" (pp. 129) -, affirms that happiness is an intellectual operation, prescribed and regulated by intellect; an honest operation, submitted to the recta ratio, practiced during one's whole life, or for a long period of time. In addition, the author makes it clear that, in this life, neither active happiness nor contemplative is perfect; and simple contemplation does not coincide with purity of habits. However, contemplative happiness is still considered more perfect than the active one. Accordingly, Góis follows Thomas Aquinas's thoughts, because of his discussions about happiness of beatific vision.

The Jesuit theologian Francisco Suarez (1548 1617), who follows the same line of the second Scholastics of Góis (being therefore included in the Thomist tradition), teaches that "beatitude" - another term for "happiness" (beatitudine) -is a product of the simultaneous mobilization of intelligence and will: the intelligence illuminates and recognizes the Good and the will prompts the other potencies to conquer this Good. Then, according to this perspective, happiness cannot be understood as a single Good, recognized in its own terms, and only achievable through a mystical visio Dei - even if we consider contemplation as the

\footnotetext{
"Como convém assentar a felicidade no que se diz feliz, e conste da anterior disputa que a felicidade não reside nos bens do corpo, conclui-se que se situa nos bens da alma. E mais: como os bens da alma, se falarmos de um modo geral, são potências, hábitos e operações, e os dois primeiros se ordenam para a operação, e a felicidade é desejada por si mesma - deve-se afirmar, por consequência, que a felicidade consiste na operação da alma”.
} 
most perfect activity in the way to happiness. Men, therefore, have to work hard and make an effort to achieve it, and these habits constitute the active search of bonum arduum in this life. Here we understand that not only are the faculties of the rational soul involved in this dynamics, but also the passions of soul, the concupiscent appetites (the ones that are moved by the simple acknowledgment of good) and irascible appetites (the ones that are moved towards the apprehension of the arduous good) (see Massimi, 2001).

If we examine the way the spiritual life norms in the Society of Jesus are constituted, we, immediately, identify the same categories described in the Jesuit Philosophical-Rhetorical universe. For instance, in The Spiritual Exercises, more specifically in "Rules to understand movements in the soul", Ignatius of Loyola $\left(16^{\text {th }}\right.$ century/1991a), describes consolation (see O’Malley, 1993/1999):

I call it consolation when some interior movement in the soul is caused, through which the soul comes to be inflamed with love of its Creator and Lord; and when it can in consequence love no created thing on the face of the earth in itself, but in the Creator of them all. Likewise, when it sheds tears that move to love of its Lord, whether out of sorrow for one's sins, or for the Passion of Christ Our Lord, or because of other things directly connected with His service and praise. Finally, I call consolation every increase of hope, faith and charity, and all interior joy which calls and attracts to heavenly things and to the salvation of one's soul, quieting it and giving it peace in its Creator and Lord. (pp. 80) .

This definition of consolation coincides with what has been written about happiness, considering that consolation consists of recognizing the Highest Good - man's "Creator and Lord" - at the same time that it carries with itself the love endeavor, a movement towards to "heavenly things and to the salvation of one's soul", and also the corollary ("interior joy" and peace) of this dynamism of contemplation of real signals of the Creator's mysterious presence, and the ordered action to serve and praise this Presence (see Loyola, $16^{\text {th }}$ century/1991b, pp. 224). Everything mentioned above is part of the recognition of man's ultimate vocation.

The same description appears in the Spiritual Diary when, for example, Ignatius of Loyola describes the "spiritual intelligences" he felt about the Blessed Trinity. It is also present in The Autobiography of St.
Ignatius, in several passages, especially when his biographer reports that Ignatius used to think of God as his "master", teaching him every step:

He had great devotion to the Blessed Trinity above all. Every day he prayed to each of the three Persons and to the whole Trinity. While praying to the Blessed Trinity, he wondered how he could offer four different prayers to the Divinity. This thought, however, caused him little or no trouble. Once, while reciting the little hours in honor of the Blessed Virgin at the steps of the monastery, he became immersed in deep thoughts. He seemed to behold the Blessed Trinity in the form of torch; this vision affected him so much that he could not refrain from tears and sighs. On the same day he followed the procession from the church, but even until the suppertime he could not withhold his tears, and after that his joy and consolation were so great that he could speak of no subject except the Blessed Trinity. In these conversations he made use of many different comparisons to illustrate his thoughts. Such was the impression made on him on that occasion that during his life, whenever he prayed to the Blessed Trinity, he could experience great devotion. (Loyola, $16^{\text {th }}$ century /1991a, pp. 1033-1034, our translation).

It is interesting to notice that his devotion to the Blessed Trinity generated the same experience of consolation, in a period that precedes the writing of the Spiritual Diary (1544 - which corresponds to the beginning of his process of conversion). Indeed Ignatius has become a "model of experience" (see Marin, 1996. For a better understanding of the term "experience", see Mendiola, 2003; Schmitt, 1969; Pacheco, 2004). It happens not because he had a certain extraordinary experience at a particular moment of his life, but because he committed himself to his mission, every day, the rest of his life, increasing his familiarity with the Trinity, aiming at achieving the degree of perfection and happiness which would make him an example of life not only for his companions, but also for the Church and the world.

The text in Constitutions illustrates how Ignatius's life was exemplary and this text is acknowledged as a group of precepts for the Society of Jesus. At the Second Chapter ("Who the Superior General is supposed to be") of Part IX ("Concerning the head and the government from which it proceeds"), there is: 
Concerning the qualities the Superior General should have, the first one is that he should be connected to Our Lord and have great familiarity with Him in his prayers and other activities, so that he could receive, from God, source of all Good, an abundant participation of all His gifts and graces in favor of the Society, so as great force and efficacy for all means that he is going to use to help the souls. Second: he must be a man who, with the example of all virtues, helps the other members of the Society. Charity has to resplend in him, and also true humility, which makes him amiable to God and every other man. In addition, he has to be free of all passions, keeping them tamed and mortified, so that internally they do not disturb the judgment of reason; and he has to be so selfcontained, so concentrated on his purposes, that nobody will notice anything that is not supposed to edify members of the Society, who should have him as a mirror and model. (Loyola, $16^{\text {th }}$ century/1991a, pp. 580, $\S ~ 723-$ 726 , our translation).

This union to God, this "familiarity", the "example of all virtues", the "charity", "humility", mortification of the passions and being "selfcontained" to which the text refers are not descriptions of general qualities, but the very prescription of the "Ignatian model": it has to be the mirror of every Jesuit and each one who encounters a Jesuit, so that the "purpose of this Society" is accomplished - "not only be committed, with divine grace, with the salvation and perfection of our members' souls but, with the same grace, try to help the salvation and perfection of anyone" (Loyola, $16^{\text {th }}$ century/1991a, pp. $396, \S 3$ ).

Consolation is the safe consequence of an objective relationship with someone who "occupies (...) Jesus Christ's place" (Loyola, 16 $6^{\text {th }}$ century/1991a, pp. 460-461, § 263), someone with whom the Jesuit identifies himself in the period of probation (when Jesuits go through the necessary way to become a true companion to Jesus as Ignatius himself was and so many other saints and martyrs) and opens himself confidently as a way to gradually acquire selfknowledge.

In the Constitutions, it is possible to see that the experience of consolation is not conceived as an isolated experience, a product of special grace to few people, or a product of an individual stoic ascension, but it is intimately connected to the experience of unity either among the dispersed members of the Society or among them and their superiors; it is, thus, expressed through the internal or external uniformity.
Besides, it is pointed that "a contempt for temporal things" is necessary for having the truest experience of consolation, as these things are "occasions of disorder" - "the main enemy of union and universal good". This contempt can only be efficient when the person leaves its self and is open for the creatures. Besides, only the ones "who have both their eyes fixed on heaven" (Loyola, 16 $6^{\text {th }}$ century/1959, pp. 32, Letter to Pietro Contarini, August 1537) are not torn apart, not deceived and not united to Christ, to the Church and to the Society of Jesus, experiencing, finally, the happiness of

having nothing at the same time of having everything.

Everything was promised by Our Lord, to be given in addition to those who seek first His kingdom and His righteousness. If everything is given to those who seek His kingdom first and his righteousness, can anything be denied to those who only seek the justice of the kingdom and the kingdom itself? (Loyola, $16^{\text {th }}$ century/1991a, pp. 654 , our translation).

In order to reach the happiness derived from the union and familiarity with the "essential one", the "entire" man has to make a choice. That is how Ignatius expresses his thoughts in a letter to Alphonso Ramirez de Vergara sent on March 30, 1556:

The way to experience through the heart and execute softly what reason states as the greater service and glory to God, the Holy Spirit will teach you better than anyone. It is true that, to elevate to the best and most perfect things, the movement of reason is sufficient; however, the movement of will, not preceding decision nor execution, would not let them be followed, because God Our Lord compensates the trust in Providence, the entire abandon of himself and the renouncement to personal consolations, and $\mathrm{He}$ attributes great contentment, relish and spiritual consolation more abundantly than expected, and searches purely his glory and good pleasure. It pleases His infinite and magnificent benevolence to guide everything that concerns you according to what he sees as more convenient in that occasion. (Loyola, $16^{\text {th }}$ century/1991a, pp. 984 , our translation).

The movement introduced by reason is "sufficient", but, through will, the person renounces himself and adheres to God's call, receiving "a more plentiful taste and consolation" than it was expected in the beginning. If will is forced, man's freedom 
disappears: only through the free application of will, in an understandable obedience, full of reasons, man is able to (cor)respond God's call and to achieve realization and definitive consolation already in this life. Only offering his understanding, freedom and will, man is able to say fiat ergo voluntas tua in every things and gestures, with the purpose of reaching the "only necessary one".

And what does man's freedom consist of? Nieremberg (1640/1957) answers: “God's children's freedom is exactly this: the contempt for the world, the tranquility of the soul, the conformity with the divine will, the true prudence; and the basis of every virtue is to acknowledge that we are born just to serve our Creator" ${ }^{\prime 6}$ (pp. 249, our translation). And what else can be said about this state of freedom, in which man is constantly in love with the Truth (the "basis and the immovable foundation" of every happiness that it desires)? According to Nieremberg (1640/1957), it is necessary to enumerate the use of "Reason": it permits "Truth to exist", "it comes from heaven", "it proceeds from God, its first and natural Origin" (pp. 473); "Reason" brings comfort and facility, "transforms all spines into roses", even though with "Heaven's assistance", because it "has undoubtedly necessity of Grace; from where must come its greater and safer help" (pp. 377-378, our translation).

We now move to the analysis of the Indipetae taking into account the macro-historical point-of-view. Here we find constant use of terms related to the topos of consolation that has been described in this article.

The examination of the frequency of terms in each of the rhetorical parts of the letters - captatio benevolentiae, narratio, petitio, conclusio and valedictio -, reveals a significant relationship: in the first and the last parts, commonplaces such as "consolation", "joy" and "contentment" practically disappear or they are only used when the indipetente, describes the consolation he experiences because of the desires about this mission or, in conclusio, the indipetente summarizes the content of his letter, referring to the "consolation" he has felt when he discovered in the blotting-paper the content of the letter he had just written (see ARSI, Indipetae Hispanae, FG 758, letter no. 116).

Then it is in the narratio and in the petitio, even more in the former, that terms connected to the topos of consolation will appear more frequently. In the

6 "En esto está la libertad de los hijos de Dios: el desprecio del mundo, la tranquilidad del ánimo, la conformidad con la voluntad divina, la verdadera prudencia; y es fundamento de toda virtud mirar que no nacimos sino para servir a nuestro Creador solamente". narratio, the Jesuit is expected to explain to the Superior General the reasons that make him believe that the elective process in which he is involved is right. Besides, the indipetente has to express clearly that the consolation and joy he experiences are the basis for the judgment of veracity.

If, on the contrary, the petitioner felt "sadness", "abatement", "weakness", and had "funest and deceiving thoughts" or lost his confidence (see Loyola, $16^{\text {th }}$ century/1991a, pp. 645, Letter sent by Ignatius of Loyola to Teresa Rejadell, on June 18, 1536), he should be certain that everything he felt was temptation and he was deceived by the "enemy of human nature". Thus, expressing his consolations, joy, contentment, pleasure in this part of the indipeta would always demonstrate his certainty about the divine origin of the desires the petitioner feels.

When the terms just mentioned appear in the petitio, they are usually connected to the petitioner's pleas to the superior for having his desires accomplished or allowing God's will being fulfilled in this life, according to His plans. The use of such topoi here has a narrow connection with the experience of indifference: the interest is consolation, no matter how it happens, as man feels the perfect "indifference that my Institute asks me"7 (see ARSI, Indipetae Hispanae, FG 758, Letter no. 43, our translation).

Bernardo Matias, for instance, begins his letter of petitio with comments about the consolation he felt when he heard about "the deaths or, rather, the new lives of so many martyrs" 8 (ARSI, Indipetae Hispanae, FG 758, Letter no. 80, our translation) in the Eastern Indies. It is worth mentioning that, in the case of this indipeta, the comment just transcribed is placed in the captatio benevolentiae: the letters produced in the scope of the Society of Jesus should present edifying content, and Bernardo Matias does it, when he writes about the consolation he experiences after he was told about the martyrdom of several Jesuits, and his writing would certainly dulcify the Superior General's intention. In the same letter, Bernardo Matias only returns to the same commonplace in the petitio, when he says "I would be consoled to know that Your Paternity has received some of my letters"9 (see ARSI, Indipetae Hispanae, FG 758, Letter no. 80, our translation).

\footnotetext{
"indiferençia que mi Instituto me pide".

8 "de las muertes o por mejor desir de la nueva vida de tantos mártires".

9 "cierto yo me aconsolaria mucho de saber el rescibo de alguna mia por no enfadar a Vuestra Paternidad".
} 
Another petitioner who uses the topos of consolation in the first part of his letter is Alonso Cortes who explains, at the very beginning, that he intends to expose to the Superior General his wishes concerning the mission so that this acknowledgement would make him "pleased with whatever is ordered to me and I will be certain that I will have accomplished God's will"10 (see ARSI, Indipetae Hispanae, FG 759, Letter no. 13, our translation). There is a different usage of the topos if we compare to Bernardo Matias's letter: here, contentment is connected to the topos of obedience, describing what an author of the Society of Jesus once said when he enumerated the fruits of obedience - security, freedom and soul's quietness.

Seraphin Bonaventura Coçar, in his turn, reports the work of discernment of spirits saying that he experiences a desire that makes him feel "very consoled and pleased so that I believe I am able to face any difficulty, and any work offered to me would be soft" difficulties makes him say it is "Our Lord's call and vocation" $" 12$ (see ARSI, Indipetae Hispanae, FG 758, Letter no. 4, our translation).

Balthasar de Torres also states that his heart is so much on fire after dedicating himself for five or six months in "the matters in Japan", , that if, on that day, "I was sent in mission, interrupting my studies, I would go with great spiritual consolation" ". Here, consolation is not an experience that he has gone through and elaborated at the moment of writing, but it is a promise and a certainty produced by the "great desires" he has to imitate the priests who work in Japan, a desire that emerged after he read and saw "more attentively what the priests do in the Eastern Indies, especially in Japan" ": the consolation with the imitation of those who have become examples for the whole Society of Jesus, for the Church and for the world, carrying out the factus of every man to give glory to God, allowing the world to recognize God through his own life, as Christ's, for the good

10 "contento con lo que de mi ordenare, y piense aver hecho lo que de mi parte en razón de cumplir aquello, a que la divina Voluntad me llama”.

11 "muy consolado, y con tal alegria que me parece bastante para arrostrar a qualquiera dificultad y trabajo que por entonces se me podria ofrecer, y de hecho se me haze todo suave".

12 "llamamiento y vocacion de Dios Nuestro Señor".

13 "delas cosas de el Japon".

14 "embiasen, interrumpiendo mis estudios, me partiera con grande consolacion de mi spiritu".

15 "con mas attention, que otras veçes solia, lo que nuestros padres hacen en las Indias orientales, specialmente en el Japon". destiny, for the good and happiness of humanity. He mentions the issue of consolation only in the petitio, writing: "it will be great consolation all days of my life, and during my death, to have always worked with obedience and for the good of the souls, without mixing it to my own will"16 (ARSI, Indipetae Hispanae, FG 758, Letter no. 13, our translation).

Such an experience of consolation, which, for us, modern people, may not resemble any experience of happiness, cannot be, nevertheless, understood as a simple rhetorical resource of convincement and persuasion. It is true that the philosophical-rhetorical aspect is inseparable from this dynamism; however it does not imply a separate reading of the text - we have to refer constantly to that philosophicalrhetorical-spiritual-institutional unity that supports this elaboration of experience. If we are not certain about this unity, we run the risk of saying that it is not possible to describe the experience reported in the Indipetae: the fragmentation of the document means ruining the source.

In all the other letters, the term "consolation" is marked by expectation, hope, trust or certainty: it is always a future experience, upon which the argumentation is built... the same final beatitudine described before.

Another letter in which there is the dynamics of a more present and concrete consolation is the one written by Diego de Salcedo, which is actually the one that contains more topoi connected to consolation. The author describes the comfort he used to feel when the "letters from Japan and other places"17 were read: "I was consoled when listening to them, and I used to feel great pleasure, as if I was there, living with them (the priests)" ${ }^{\prime 18}$. Here, pleasure and consolation are so strong and live experiences that they resemble the ones the author would feel if he had the chance to fulfill his desires. Afterwards, Salcedo writes "if I received one single letter by Your Paternity letting me go, I would do it at once and with no doubt, very happy and pleased" ${ }^{, 19}$, one more time, although here it means future joy. After that, in the petitio, he states that going in mission would be the "thing that would

\footnotetext{
16 "sera muy gran consuelo todos los dias de mi vida, y a la hora de mi muerte, aver travajado solo por obediencia, y bien de las animas; sin mescla de propria Voluntad".

17 “cartas de Japon y otras partes".

18 "me consolava mucho de oyelas, y me regozijava interiormente pareciendome que yo me hallaria alla con ellos [los Padres] conviviendo".

19 "si me viniera una suia sola, que me significase que me fuese, me fuera luego sin duda muy contento y regozixado".
} 
bring me more contentment [and] joy now on earth" 20 . The references to consolation do not end in the elaboration of his personal experience, but they are extended to the point of talking about the consolation that his story has caused in others and that he expects it to have the same effects in the Superior General: "Father Esteban Paez has asked me to send Your Paternity those letters which have given him a lot of comfort; and he also told me that the realization of my desires would be in Your Paternity's hands"21 (see ARSI, Indipetae Hispanae, FG 758, Letter no. 191, our translation).

Joan Sotalell also makes references to consolation and relief experienced after hearing about the Indies:

I have observed that, at many times, when a temptation or another thing afflicts me, the way I have found to overcome it is to think, patiently, that I may go to the Indies; soon, the temptation disappears, and I feel comforted to do what previously seemed hard. (...) Our Lord has given me so great consolations and has shown that He loves me that the only thing I can offer in exchange is to ask Him to die in the name of His love, a cruel death, and that it happens only after working hard in the same Indies ${ }^{22}$ (ARSI, Indipetae Hispanae, FG 758, Letter no. 338, our translation).

These extracts therefore reveal a very peculiar dynamism of the Jesuit pedagogy. It is based on the Aristotelic-Thomist Philosophical Anthropology in which the process of modification of the temperaments does not begin immediately with reason and will, but with the senses that "listen" and "experiment" certain things. These things, when passing through ratio particularis - after their perception by external senses and the first assimilation by the senso communes and by the transformation of

20 "cosa que mas contento [y] alegria me poderia traer aora en la tierra".

21 "El Padre Esteban Paez me escrebio que yo le embie aquellas cartas que e dicho que se consolara harto de que estubiera en su mano el cumplimento de mi deseos".

22 "Y tengo experimentado que muchas vezes, quando alguna tentacion o otra cosa alguna me aflige, el medio para vencella, es pensar que si la como con paciencia yr a las Indias, luego se deshaze como humo, y siento despues grande consuelo y facilidad en hazer lo que antes me parecia muy pesado. (...) me dio Nuestro Señor tan grandes consuelos, y muestras de lo mucho que me amava que no pude ofrecer en pago de tan grande amor, como pedirle, que muera yo por su amor, una muerte cruel, y estos despues de muchos y grandes trabajos en las mismas Indias padecidos". the image in the imaginative potency, with the suitable species for the "conversion" or the "spiritual utilization" - reach easily the intellect, which mobilizes will to make a choice in the most virtuous way, leading to happiness (see Bergamo, 1994; Massimi, 2001).

In relation to Juan Bravo's letters, the term consolation (or similar ones) only appears in the first letter, and always in the captatio benevolentiae, which explains the double use - the first one, when Bravo talks about the consolation he feels for writing to the Superior General: "With great consolation I write you, Your Paternity, because of the little joy I experiment knowing that it is the first letter I send you"23. And the second use, in which the petitioner talks about the consolation he expects to provoke in the Superior: "And I believe that Your Paternity's consolation will not be smaller as for those who cares for his children's spiritual well-being",24 (ARSI, Indipetae Hispanae, FG 758, Letter no. 329, our translation).

In other letters by Juan Bravo, all the references to the topos of consolation is eliminated and the text becomes full of "impatience" (ARSI, Indipetae Hispanae, FG 758, Letter no. 404), "indignity” (ARSI, Indipetae Hispanae, FG 758, Letter no. 404), "miseries" (ARSI, Indipetae Hispanae, FG 758, Letter no. 404), "scourging and punishments" (ARSI, Indipetae Hispanae, FG 758, Letter no. 404), "imperfections" (ARSI, Indipetae Hispanae, FG 759, Letter no. 4), "resignation" (ARSI, Indipetae Hispanae, FG 759, Letter no. 4), describing more the experience of desolation than its opposite. However, as it is indicated in The Spiritual Exercises - "Let him who is in desolation consider how the Lord has left him in trial in his natural powers, in order to resist the different agitations and temptations of the enemy" (Loyola, 16 ${ }^{\text {th }}$ century/1991a, pp. 89) -, this Jesuit seems to demonstrate how he is engaged in the process of changing this condition of desolation into consolation, especially in the last letter,. He says

It gives me comfort and confidence the great desire that Your Paternity has of fomenting and encouraging every departure of his

23 "Con mucho consuelo myo escrivo esta a Vuestra Paternidad parte por ser la occasion con que la escrivo tal quales parte tanbien por que me da no pequeña alegria ver que siendo la primera que a Vuestra Paternidad escrivo sea con tal occasion".

24 "Y creo que no sera de menos consuelo a Vuestra Paternidad como a quien tanto desea el bien espiritual de sus hijos". 
spiritual sons. And, therefore, I wait in Our Lord that it [my desire], still full of contradictions of demon and my imperfections, may be placed under the light and the warm and paternal affection and love of Your Paternity ${ }^{25}$ (ARSI, Indipetae Hispanae, FG 759, Letter no. 4, our translation).

Considering what has been discussed so far, it is possible to see that there are several elements that may describe the experience of consolation: a corollary or not of a life to be lived according to God's will; an end or not of a life of search, of constant peregrination, of endless work of undeceiving the world, of looking to the bottom of reality; a decisive answer to the expectation of beatific vision, when "then, face to face" (I Cor 13,12) we will be infinitely happy and transfigured; satisfaction, perfection finally conquered; something to be lived afterlife or a nowand-here activity. As it was seen, the experience described in the letters embodies the grammar of present use in the founding documents of the Society of Jesus.

The experience of consolation - present, past or future (experience, memory or hope) -, in the letters Indipetae, seems to be the indication of that happiness to which every man is assigned, according to this philosophical anthropology. The experience of consolation, as a term that designates the dynamism that conducts to the final freedom, is the happy result of a life of dedication to reality in the world that surrounds the Jesuit - a "sacramental" world (see Pécora, 1994) -, and also in the one that is hidden inside - the analogy to the Mystery, the Alpha and Omega. The experience of consolation is the effect of an obedience, which is nothing more than the adhesion to the last end, identified in the work of selfknowledge (See Pacheco \& Massimi, 2005) and attention to the world and other people.

It could seem to be obvious that a view of history and a special attention to our own experience reveal that a simple affirmation of reality - far from the insistence on the images we have about ourselves and the surrounding world - allows self-realization, consolation, or happiness - exigencies and sparks that put us always on the move. Then, what amplitude of

25 "Me asegura y da confiança el deseo grande que reyna en Vuestra Paternidad de fomentar, y alentar qualquier buen parto de sus espirituales hijos. Y asi espero en el Señor, que este myo [deseo], aunque contrastado del demonio, y de mys imperfecçiones, Vuestra Paternidad con el calor de su Paternal affecto y amor le ha de sacar a luz". conscience we, psychologists, should prove for the archeological work of our experience's excavation shows the exigencie's space, constituting the human, and makes of our job - more than a technique - the offering of a friendship to those who are looking for this path?

\section{REFERÊNCIAS}

Bergamo, M. (1994). L'anatomie de l'âme: de François de Sales à Fénelon [Anatomy of the soul: of François de Sales to Fénelon]. (M. Bonneval, Trans.). Paris: Jérôme Millon (Original work published 1991).

Fabre, P. A. \& Romano, A. (1999). Presentation. Revue de synthèse, 120 (2-3), 247-260.

Fernández-Martos, J. M. (1991). La incorporación de la realidad como clave del cambio en los Ejercicios Espirituales [The incorporation of the reality like a key of the change in the Spiritual Exercises]. In C. Alemany \& J.A. Garcia-Monge (Eds.). Psicologia y Ejercicios Ignacianos (vol I): la transformación del yo en la experiencia de Ejercicios Espirituales (pp. 241-276). Bilbao: Mensajero e Sal Terrae.

Giussani, L. (2000). O Senso Religioso [The Religious Sense]. (P.A.E. Oliveira, Trans.). Rio de Janeiro: Nova Fronteira (Original work published 1997).

Góis, M. (1957). Disputas do Curso Conimbricense sobre os livros de Moral a Nicómaco de Aristóteles em que se contém alguns dos principais capítulos da moral. [Conimbricense Course of the Nichomachean Etichs by Aristotle]. (A.A.B. Andrade, Trans.). Lisboa: Instituto de Alta Cultura (Original work published 1593).

Lamalle, E. (1981-1982). L'archivio di um grande Ordine religioso: L'Archivio Generale della Compagnia di Gesù. Archiva Ecclesiae, 24-25, 89-120.

Longo, N. (1981). De epistola condenda: L'arte di "componer lettere" nel Cinquecento. [De epistola condenda: the art of "componer lettere" in the $16^{\text {th }}$ century]. In A. Quondam (Ed.). Le "carte messaggiere": retorica e modelli di comunicazione epistolare: per un indice dei libri di lettere del Cinquecento (pp. 178-198). Roma: Bulzoni Editor.

Loyola, I. (1991a). Écrits [Writings]. (M. Giuliani, Ed.). Paris: Desclée de Brouwer; Bellarmin (Collection Christus, 76, Textes) (Original published 16th century).

Loyola, I. (1959) Letters (W. J. Young, Trans.). Chicago: Loyola Press (Original published $16^{\text {th }}$ Century).

Loyola, I. (1991b). The Spiritual Exercises (Father Elder Mullan, Trans). New York: Printers to the Holy See (Original published $16^{\text {th }}$ Century).

Marin, L. (1996). Le Récit, réflexion sur un testament [The Autobiography, reflexion of a will]. In L. Marin (1999). L'écriture de soi: Ignace de Loyola, Montaigne, Stendhal, Roland Barthes (pp. 137-155). Paris: Presses Universitaires de France.

Massimi, M. (2001). A Psicologia dos Jesuítas: Uma Contribuição à História das Idéias Psicológicas. Psicologia Reflexão e Crítica, 3(14), 625-633.

Massimi, M. e Prudente, A.B. (2002). Um incendido desejo das Índias... [A strong desire of the Indias...]. São Paulo: Ed. Loyola. 
Mendiola, A. (2003). Un nuevo reto a la interpretación de las crónicas de la conquista: historizar el concepto de experiencia [A new challenge to the interpretation of Chronicles of the Conquest: the history of the experience concept]. Unpublished manuscript.

Nieremberg, J. E. (1957). De la diferencia entre lo temporal y eterno [Of the difference between the temporal and the eternal]. In E. Zepeda-Henriquez (Ed.). Biblioteca de Autores Españoles, desde la formación del lenguaje hasta nuestros dias (Volume 104). Madrid: Ediciones Atlas (Original work published 1640).

O'Malley, J. W. (1999). I primi gesuiti (A. Schena, Trad.). Milano: Vita e Pensiero. (Original work published 1993).

Pacheco, P. R. A. (2004). Experiência como fator de conhecimento na psicologia-filosófica aristotélico-tomista da Companhia de Jesus (séculos XVI-XVII). Memorandum, 7, 58-87. Retrieved November 1, 2004, from http:// www.fafich.ufmg.br/ $\sim$ memorandum/ artigos07/ pacheco01.htm

Pacheco, P. R. A. \& Massimi, M. (2005). O conhecimento de si nas Litterae Indipetae. Estudos de psicologia (Natal), 10(3), 345-354.

Pécora, A. (1994). Teatro do Sacramento: a unidade teológicoretórico-política dos sermões de Antonio Vieira [Theater of the Sacrament: the unit theological-rhetorical-politics of the sermons of Antonio Vieira]. São Paulo: EDUSP.

Pécora, A. (1999). Cartas à Segunda Escolástica [Letters like the Second Scholastic]. Em A. Novaes (Ed.). A outra margem do Ocidente (pp. 373-414). São Paulo: Companhia das Letras.
Pécora, A. (2001). Máquina de gêneros: novamente descoberta e aplicada a Castiglione, Della Casa, Nóbrega, Camões, Vieira, La Rochefoucauld, Gonzaga, Silva Alvarenga e Bocage [Machine of types: again discovered and applied to Castiglione, Della Casa, Nóbrega, Camões, Vieira, La Rochefoucauld, Gonzaga, Silva Alvarenga e Bocage]. São Paulo: Editora da Universidade de São Paulo.

Schmitt, C. B. (1969). Experience and Experiment: a comparison of Zabarella's view with Galileo's in De motu. Studies in the Renaissance, 16, 80-138.

Tin, E. (2003). "Familiar del Universo": arte epistolar e lugarcomum nas cartas familiares (1664) de d. Francisco Manuel de Melo. Unpublished master's thesis, Curso de Teoria Literária do Instituto de Estudos da Linguagem da Universidade Estadual de Campinas, Campinas/SP, Brazil.
Endereço para correspondência:
Paulo Roberto de Andrada Pacheco. Rua Espártaco, 251/01, Vila Romana. CEP 05045-000, São Paulo-SP, Brasil.E-mail: paulopac@yahoo.com.br.
Recebido em 28/05/2008

Aceito em 22/09/2008 